\title{
The Influence of Tax Revenue on Government Capital Expenditure and Economic Growth in Nigeria
}

\author{
Osho, Augustine E. Ph.D \\ Department of Accounting, Achievers University, P. M. B. 1030, Owo, Nigeria \\ Olemija, Temidayo Lawrence \\ Department of Accountancy, Rufus Giwa Polytechnic, P. M. B. 1019, Owo, Nigeria \\ Falade Aderemi Bukunmi \\ Finance Department, Dormanlong Protective Coatings Limited, P. O. Box 256, \\ Oko-Oba Agege, Lagos State, Nigeria
}

\begin{abstract}
This study examined the influence of tax revenue on government capital expenditure and economic growth in Nigeria. It specifically evaluated the significant effect of companies' income tax on government capital expenditure in Nigeria; the level of significance of petroleum profit tax on government capital expenditure in Nigeria; the significant impact of value added tax on government capital expenditure in Nigeria; and the long run relationship between tax revenue and government capital expenditure in Nigeria. The study used relevant secondary data that span from 2009 to 2018 extracted from series of published central bank statistical bulletins. Public finance analysis model $(\mathrm{CAPEX}=\mathrm{f}(\mathrm{CIT}, \mathrm{PPT}, \mathrm{VAT}))$ was formulated and was tested with the use of descriptive analysis in the form of minimum and maximum values, mean and coefficient of variation, while inferential statistics in the form of multiple regression, T-Test, Johansen's co-integration test, coefficient of multiple determinations, F-test, DW-test. Findings revealed that Companies' Income Tax had a positive relationship with capital expenditure; Petroleum profit tax (PPT) had a negative effect on the financing of government development project; value added tax (VAT) had insignificant positive relationship with total government capital expenditure (CAPEX). It is concluded that tax revenue does not impact the spending on capital expenditure. The study recommended that utilization of tax revenue on public goods will encourage the payment of tax by tax payers.
\end{abstract}

Keywords: Economic Growth, Government Capital Expenditure, Government Expenditure, Tax Revenue, Taxation

DOI: $10.7176 / \mathrm{EJBM} / 11-2-05$

\section{Introduction}

In the country we are today, different irregularities leading to public outcry and perpetual increasing fraud in government sector activities resulting from an inappropriate public finance planning and implementation mostly in some of the developing countries. Banks and businesses organizations were collapsing thereby leading to crisis of confidence in internal and external activities in the country due to poor governance. The reason behind this is corruption, indiscipline, lack of accountability which is the hall marks of our society in developing countries resulting into decrease in growth and development.

Economic growth represents the expansion of a country's potential GDP or output Olopade \& Olopade, 2010). Growth models that incorporate public services, the optimal tax policy lingers on the characteristic of services. Economic growth has provided insight into why state growth at different rates over time; and this influence government in her choice of tax rates and expenditure levels that will influence the growth rates (Nazifi, 2014 \& Nwaeze 2010).

The narrow goal of development (economic growth) induced nations to focus their energies narrowly on the rapid growth of national incomes (Todaro \& Smith 2003). "To maximize income growth, environmental considerations were left to languish on the sidelines; the standard of living was often allowed to slide; large inequalities between classes, regions, and genders were ignored; and poverty was tolerated more than it should have been in the rush to generate maximum growth" (Basu 2000). It was then scholars and policy-makers in most developing countries who realized that income growth was only one dimension of development; a new economic view of development has arrived. The state spends on the defense, education other social services. It also spends on servicing national debts, capital investment such as Airport, etc. Government also spends on i

ts own maintenance as well as on other countries and governments. Public or government expenditure therefore is the expenses of the government for its own maintenance and on the society and the economy as a whole. The state is getting increasingly involved in economic activities and in transfer payments to other countries. As a result, public expenditure has maintained an upward trend over time in virtually all the countries of the world (Maku, 2009). The major items of public expenditure in Nigeria include: administration, economic 
service, infrastructure and social amenities, national security and defence, grants and aids and interest on loans.)

Public expenditure could be broadly classified into recurrent expenditure ad capital expenditure. The expenditure of government which occurs regularly throughout the year is referred to as recurrent expenditure. Capital expenditure on the other hand are the expenditures of government on the acquisition of things of permanent nature (Nwaeze 2010). They include all expenditure on capital projects such as buildings, construction of roads, bridges and all permanent structures and assets.

A tax is a fee charged or levied by the government on a product, income, or activity. If it is levied directly on personal or cooperate income, it is called a direct tax. If it is levied on the price of a good or services, then it is called an indirect tax. The main reason tor taxation is to finance government expenditure and to redistribute wealth which translate to financing development of the country (Ola, 2001; Jhingan, 2004; Musgrave and Musgave; 2004 and Bhartia, 2009). Whether the taxes collected are enough to finance the development of the country will depend on the needs of the country and country can seek alternative sources of revenue to finance the development of the country will depend on the needs of the country and countries can seek alternative sources of revenue to finance sustainable development (Unegbu \& Irefin, 2011). Government collects taxes in order to provide an efficient and steadily expanding non-revenue yielding services, such as infrastructureeducation, health, communications system etc, employment opportunities and essential public services (such as the maintenance of laws and order) irrespective of the prevailing ideology or the political system of a particular nation.

This study therefore attempts to address the issues on the influence of tax revenue on government capital expenditure and economic growth in Nigeria with the view for remedying the country's revenue potentials for enhanced wealth creation and development.

\subsection{Literature Review \\ 2.1 Conceptual Framework \\ 2.1.1 Concept of Taxation}

Taxation is not a new word in Nigeria or the world as a whole. In Nigeria, taxation has been in existence even before the coming of the colonial men or the British. Taxation can be defined as the system of imposing a compulsory levy on all income, goods, services and properties of individuals, partnership, trustees, executorships and companies by the government (Samuel \& Simon, 2011; Yunusa, 2003). A1-Qudair (2005) defined taxation as a compulsory payment made bu individuals and organization to relevant Inland Revenue authorities at the federal, state pr local government level. Hye and Jalil (2010) sees taxation as a levy imposed by the government against the income, profit or wealth of the individual, partnership, corporate organization. Ola (1999) defined taxation as compulsory levy imposed on a subject or upon his property by the government to provide security, social amenities and create conditions for the economic well-being of the society. A precise definition of taxation by Zinaz and Samina, (2010) is that taxation is one of the sources of income for government, such income as used to finance or run public utilities and perform other social responsibilities. According to Adams (2001) taxation is the most important source of revenue for modern governments, typically accounting for ninety percent or more of their income.

Tax is also the nexus between state and its citizens, and tax revues are the lifeblood of the social contract. The very act of taxation has profoundly beneficial effects in fostering better and more accountable government (Tax Justice Network (TJNS) revenue 2012. Musgrave and Musgrave (2004) also stated that the economic effects of tax include micro effects on the distribution of income and efficiency of resources use as well as macro effect on the level of capacity output, employment, prices, and growth. However, the use of tax is an instrument of fiscal policy to achieve economic growth in most less develops countries cannot be reliable because of dwindling level of revenue generation. A critical examples of governments that have influenced their economic development through revenue from tax are; Canada. United States, Netherland. United Kingdom, they derive substantial revenue from Company Income tax. Value Added tax. Import Duties and have used same to create prosperity (Oluba, 2008).

According to Adegbie and Fakile (2011), the more citizens lack knowledge or education about taxation in the country, the greater the desire and the opportunities for tax evasion, avoidance and non-compliance with relevant lax laws. In this respect, the country will be more adversely affected because of absence of tax conscience on the part of individuals and the companies and the (allure of tax) administration to recognize the importance of communication and dialogue between the government and the citizens in matters relating to taxation.

The attitude of Nigerian towards taxation is worrisome as many prefer not to pay tax if given the opportunity the economy continues to lose huge amount of revenue though the unwholesome practice of tax avoidance and tax evasion, these loss of revenue can change the fortune of many economy particularly, developing countries like Nigeria. This problem has been lingering for so long which urgent attention and solution is overdue. The cost of collecting tax in Nigeria both social and economic cost is too high to the extent 
that if left unchecked the cost many soon out weight the benefit or value, derived from such operation and that will not be appropriate for the system. The government spends more to realize a miserable pittance. The rate of corruption on the art of tax officials is alarming as most of them connive and collude with supposed tax payers to evade and avoid tax. Sometimes, the tax officials' art, not properly rained on the modern ways of tax administration. The inadequate social infrastructures in Nigeria call for attention as to how tax revenue generated is to be expanded and accounted of especially where those in authority continue to spend these hand earned resources with reckless abandon.

Taxes are classified into direct and indirect. Yunusa (2003) and Aguolu (2004) defined direct taxes as taxes levied on the income of individual, group of individuals, and business firms and are paid directly by the person or persons on which it is legally imposed by the tax authority. Direct taxes can be classified into Personal Income tax, Company Income tax, Capital Gain tax, Petroleum Profit tax, and Capital Transfer tax. Indirect taxes are taxes levied on expenditure that is, goods and services. These taxes are paid as part of payment for goods and services purchased by the ultimate users or consumer. The incidences of this type of taxes are usually borne by the third party. Indirect taxes can be classified into the following: Import duties, Export duties and Value added tax (Yunusa, 2003).

\subsubsection{Concept of Economic Growth}

Economic growth represents the expansion of a country's potential GDP or output. For instance, if the social rate of return on investment exceeds the private return, then policies that encourage can raise the growth rate and levels of utility. Growth models that incorporate public services, the optimal tax policy lingers on the characteristic of services (Adeniyi, 2013). It has provided insight into why state growth at different rates over time; and this influence government in her choice of tax rates and expenditure levels that will influence the growth rates.

Economic growth is an essential ingredient for sustainable development. Economic growth brings about a better standard of living of the people and this is brought about by improvement in infrastructures, health, housing, education and improvement in agricultural productivity. Economic growth as a concept is viewed differently by different scholars. This is attributed to the condition prevailing at the time of these scholars. Majority accept it as an increase in the level of national income and output of a country. According to Dewett (2005), it implies an increase in the net national product in a given period of time. Todara and Smith (2006) defined economic growth as a steady process by which the productive capacity of the economy is increased over time to bring about rising levels of national output and income. Jhingan (2006) viewed economic growth as an increase in output. He explained further that it is related to a quantitative sustained increase in a country's per capita income or output accompanied by expansion in its labour force, consumption, capital and volume of trade. The main characteristics of economic growth are high rate of structural transformation, international flows of labour, goods and capital (Ochejele, 2007).

The motive to improve the quality of lives of citizens through the numerous expenses of government has motivated the study of the impact of government expenditure on the economic growth of Nigeria. Globally, government spending has been on the increase without a corresponding increase in the economic development of these nations especially in developing nations. This situation has also stimulated research in the area of government spending and economic growth and development.

\subsubsection{Government Expenditure}

This is the acquisition by governments of goods and services for current consumption to directly satisfy the individual or collective needs of the society, referred to as government consumption expenditure, while government acquisition of goods and service intended to create future benefits in referred to as government investment expenditure (government gross capital formation). All governments' acquisitions (government consumption expenditure plus government investment expenditure) are classified total government expenditure. Government expenditure can be financed by borrowing, printing of new money, taxes or revenues from government direct investments even though some the government investment are supposed to be subsidized. This presupposes that while it is not in doubt that governments spending stimulates economic growth, economic growth on the other hand stimulates government spending as changes in economic growth rate determines change in revenues accruable to the government upon which spending in based (Aguolu, 2004).

\subsubsection{Economic Growth and Government Expenditure}

No doubt, the bulk of government revenues come from proceeds from government direct, investments in Nigeria, while printing of new money and taxes have remain major components of government revenues in Nigeria, revenues from governments direct investments have dominated governments revenue streams in Nigeria. This phenomenon explains fluctuations in government expenditure over the years in Nigeria. Since rise in public expenditure greatly depends on revenue collection, and revenue collection depends on the level of economic activities it therefore follows that government expenditure depends on the level of economic activities (Osmond, Nnamocha \& Emmanuel 2015). 
2.1.5The Importance of Taxation in an Economy Raising of Revenue to Finance Government Expenditure

\section{Programmes.}

Tax plays an important role in the Nigerian society. It is a strong force for economic development in the country from the pre-colonial, colonial and post-colonial eras.

It is by far the most significant source of revenue for modern government; hence there is recent call for increase in taxation.

Revenue generated by the government can be used to carry out its expenditure programmes which include: defence, social and infrastructural services, general administration etc. for government to effectively carry out these obligations, a lot of revenue will be required. Revenue generated from oil and non-oil sources cannot be enough to execute these enormous tasks, hence tax revenue which is believed to be the most significant source of revenue to the government. Rabiu (2001) agree with this in his statement "A great majority of Federal and state government" taxes are imposed primarily for the purpose of raising revenue to finance government expenditure. This reproves why government in its annual budget limits the level of expenditure to commensurate with the projected revenue which tax plays a significant role. In essence, what taxes meant to the government to exactly what capital and gains are to individuals and business organizations.

\subsubsection{Tax Laws and Economic Development}

Musa (2009) opined that economic and social development laws and policies provide the basis for effective state action that lifts society from underdevelopment, improves the standard of living and facilities for the realization of the millennium development goals. Nigeria is in dire need of solution to its development challenges. Good laws that are well implemented would contribute to the resolution of these challenges. The first thing to do in this scenario is an attempt to review the implementation of the identified laws like the company income tax, petroleum income Act and tax reform Act. The second thing is to get relevant legislative committees and ministers, departments and agencies involved give account of their respective stewardship roles in implementation of the law. Oluba (2008) in his study on productivity of the Nigerian tax system and reports a satisfactory level of productivity of the tax system before the oil boom. The advent of the oil boom encouraged some laxity in the management of non-oil revenue sources like the company income tax, which was rectified to a reasonable extent with the commencement of the structural adjustment programme. The report underscores the urgent need for the improvement of the tax information system to enhance the evaluation of the performance of the Nigerian tax system and facilitate adequate macroeconomic planning and implementation. In our own opinion, we think the Nigeria tax system needed urgent overhauling in order for it to be effective in catering for the expenditure of the government.

The objectives of the tax system are multi-dimension in nature which includes revenue generation, resources allocation, fiscal tool for stimulating economic growth and development, social function, like redressing the rural-urban population drift as well as making everybody to be a responsible citizen in the society. The government needs to enlighten the citizen on tax as well as been effective in their use of the generated revenue.

The joint Tax Board was created in tax law by section 27 of Income Tax Management Act of 1961 to harmonize the tax administration of the country. It needs to be appreciated that the tax system offers itself as one of the most effective source of revenue and that it tends to create an environment conducive to the promotion of economic growth. However, the potency of the tax system will depend greatly on the tax measures and policies adopted. Sani (2005) opined at prompting ambition, rewarding success, encouraging private savings and investments needed to create new jobs and kindling in the people that spirit of enterprise. The regulation of Nigerian economy should also be the basic function of the tax system. Taxes should further be used selectively to induce and encourage nationally desirable economic activities, and may be offered to promote the development of backward areas of Nigeria. Sani concluded that tax concessions must be given and framed so as to ensure the companies actually carry out the underlying intention of increased economic development if the tax authority is to avoid the criticism that tax concessions only offer tax loopholes through which the agile tax payer can maneuver.

United Nations (2000), expert group stated that tax revenue contributes substantially to development and therefore, there is the need to streamline a nation tax system so as to ensure the realization of optimal tax revenue through equitable and fair distribution of the tax burden. The stark reality in most developing countries is that whilst there is severe budgetary pressure as a result of ever increasing demand for government expenditure, there is limited scope for raising extra tax revenues. Non-compliance problems with corporate persons result from technicalities and tax avoidance, poor record keeping and cash transactions. 


\subsubsection{Conceptual framework of tax revenue on Government capital expenditure and economic growth in} Nigeria

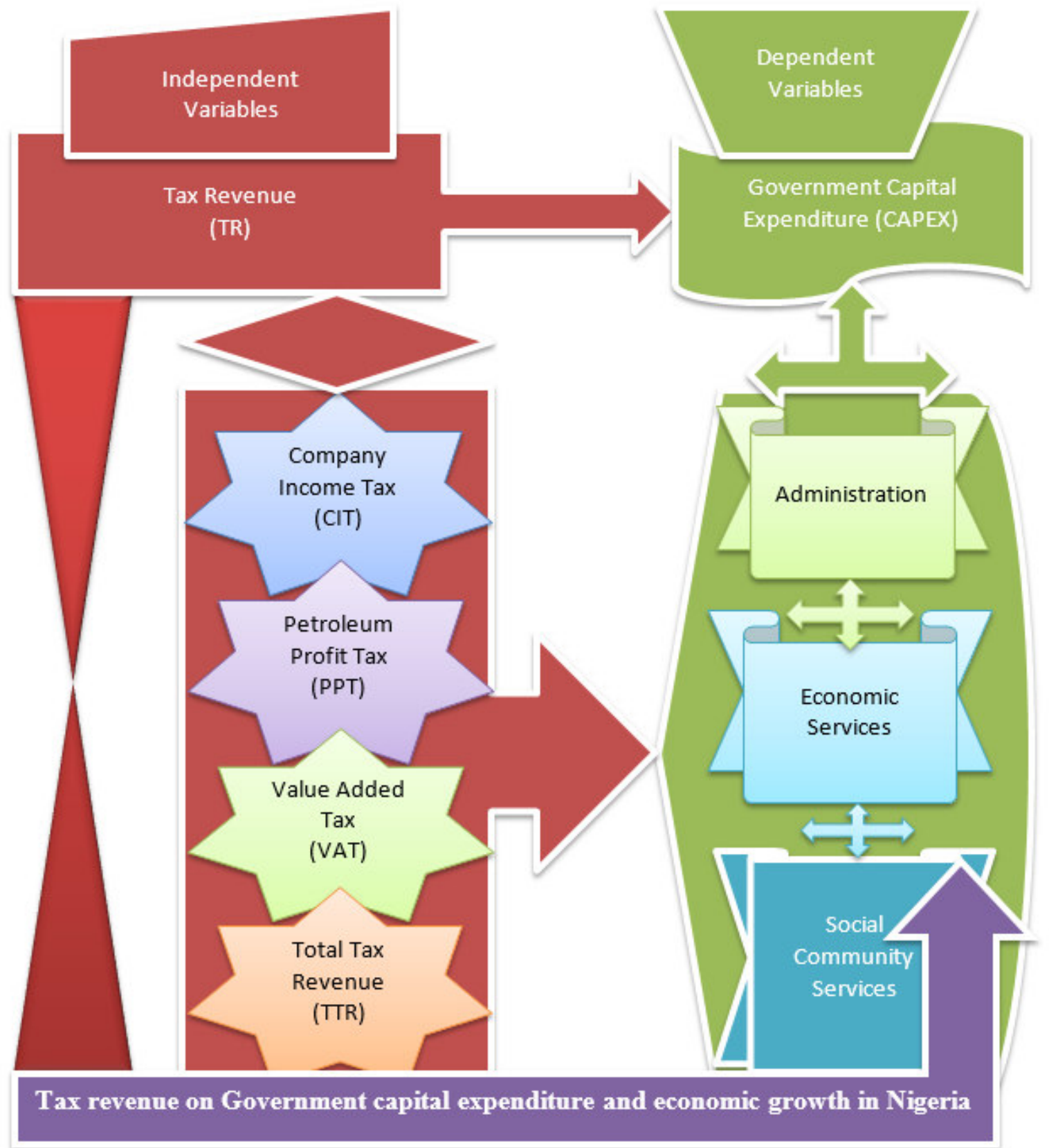

Fig 1 Source: Researchers' Conceptual framework of tax revenue on Government capital expenditure and economic growth in Nigeria Model

\subsection{Theoretical Framework}

The study examined four relevant theories which were:

2.2.1 Expectancy theory of taxation that stated that every tax proposal passes the test of practicality and must be the sole consideration before tax authorities in hid for tax proposal. It strongly emphasis that the economic and social objective of the state is considered irrelevant since it is meaningless to have tax that cannot be levied and effectively collected;

2.2.2. Ability to pay theory which focused on the income of the tax payer to meet up the tax payable and that entity or individual with higher tax base should be subjected to higher tax payment than an entity or individual with lower tax base The economists are not unanimous as to what should be the exact measure of a person's ability or faculty to pay (Naiyeju, 1996 as cited by Osho, Omotayo \& Ayorinde, 2018).

\subsubsection{Peacock and Wiseman Theory of Public Expenditure}

Allan Peacock and Jack Wisemen theory, otherwise known as PWT, was based on the political theory of public 
expenditure determination which states that government likes to spend more money, that citizens do not like to pay more taxes, and that government needs to pay some attention to the aspiration and wishes of their people. PWT attempted to explain the circular trend or time pattern of change in government expenditure in response to development in the political economy while the taxable capacity of the electorate acts as a constraint. Their theory is known as Displacement Hypothesis and is based on the experience of Great Britain. The Displacement hypothesis states that government expenditure grows in step wise fashion (Zinaz \& Samina, 2010).

The acceptance of the existence of a tolerable level of taxation which acts as a constraint on government behavior is consistent with Clark's "Catastrophe School" of taxation. PW make a destination in government expenditure growth between normal or peak time and war, crisis or social upheaval period. According to PW, during peak, public expenditures would tend to experience an upward trend, even though there may be some discrepancy between a desirable level of government expenditure and a desirable level of taxation (Fola, 2007 \& Keho, 2010). During war, famine or social upheaval this normal and steady growth in government expenditures, would be disturbed. This was as a result of the displacement hypothesis as unproductive government spending during social upheavals displaced productive government expenditure leading to rapid increase in public expenditure. Government imposes higher taxes which are regarded as acceptable during period of crisis. During this period, public expenditure is displaced upward (i.e. displacement effect). War-related expenditure displaces private and other government expenditure. However after the war or crisis, aggregate public expenditures does not fall back to its original level since a war is not fully paid for from taxation alone (Yunusa, 2003). Inspection effect may also occur as government attempts to increase expenditures to improve social conditions which have deteriorated during the period of the crisis. Government finances the high expenditures from the increase and tolerable level of taxation that does not return to its former level. There are two possible scenarios which may occur after the war or social upheaval. First, total private expenditures may return to its original growth path and second, government expenditures experienced during the war may continue in the post-war period along with an increase in civilian government expenditures until the desired growth is reached (Zinaz \& Samina, 2010).

2.2.4 Benefit theory which is the underpinning theory stated that the more benefits a person derives from the activities of the state, the more he should pay to the government; economic growth and development theory which disclosed that the real purpose of taxation is to take purchasing power from the taxpayers so that taxpayer relinquishes control over economic resources and make them available to the state. It is fiscal policy instrument which the government manipulate to achieve macroeconomic objective. According to Nwankwo, (1992) as cited by Osho, Omotayo and Ayorinde (2018), this theory states that the more benefits a person derives from the activities of the state, the more he should pay to the government.

\subsection{Methodology}

The study adopted both longitudinal research strategy and quasi-experimental research design as the research designs. The rationale behind adopting the design is after finding whether revenue derived from the administration of tax over the years' impacts government capital expenditure, while quasi-experimental research design approach was adopted because it combines theoretical consideration (a prior criterion) with the empirical observation and extracts maximum information from the available data. It enables us therefore, to observe the effects of explanatory variables on the dependent variables. The study mainly used secondary data which were analyzed with both descriptive and inferential statistics were extracted from the annual reports and statistical bulletin of Central Bank of Nigeria, National Bureau of Statistics and Federal Inland Revenue Service (FIRS). The data is for the period of 10 years ranging from 2009-2018.

The study used multiple regression, augmented dickey fuller (ADF) test, unit root test (URT), Johansen's co-integration test, standard error test, coefficient of multiple determinations, F-test, DW-test as techniques of data analysis.

\section{Models Specification}

The model specified below involved two variables namely independent and dependent variable. The independent variables were: Companies Income Tax (CIT), Petroleum Profit Tax (PPT), Value Added Tax (VAT), while government capital expenditure (CAPEX) as the dependent variable. The model was used to test all the research hypotheses.

$\mathrm{CAPEX}=\mathrm{f}(\mathrm{CIT}, \mathrm{PPT}, \mathrm{VAT})$

$\mathrm{CAPEX}=\beta+\mathrm{a}_{1} \mathrm{CIT}+\mathrm{a}_{2} \mathrm{PPT}+\mathrm{a}_{3} \mathrm{VAT}+\mu$

CIT= Companies' Income Tax

PPT $=$ Petroleum Profit Tax

VAT $=$ Value Added Tax

CAPEX= Government Capital Expenditure

\subsection{Results}

This study enquires into the empirical and quantitative analysis of the impact of tax revenue on government 
capital expenditure in Nigeria with the use both descriptive and inferential analysis. The descriptive analysis entails the use of average, standard deviation, minimum value, maximum value while the inferential analysis, involves the use of multiple regression, F-test, Augmented dickey fuller (ADF) test, unit root test (URT), Johansen's co-integration test, standard error test, coefficient of multiple determinations, DW-test. The data obtained were based on the variables identified in the research hypotheses which are: explained variable which is captured by the Government Capital Expenditure (CAPEX) and four explanatory variables which are companies' income tax (CIT), petroleum profit tax (PPT), value added tax (VAT) and total tax revenue (TTR).

\subsection{Descriptive Analysis}

The descriptive statistics was computed, so that it gives detail understanding to the trend of variables (CAPEX, PPT, CIT, VAT, TTR) and it is used as stand to give recommendations after identifying the association between the variables from correlation and regression analyses. Descriptive analysis shows the average, and standard deviation of the different variables of interest in the study. It also presents the minimum and maximum values of the variables which help in getting a picture about the maximum and minimum values a variable can achieve.

Table: 4.1 Statistics Summary, using the observations 2009 - 2018

\begin{tabular}{|c|c|c|c|c|}
\hline Variables & Mean & C.V. & Minimum & Maximum \\
\hline CAPEX & 1041.15 & 0.587792 & 519.470 & 2681.08 \\
\hline CIT & 564.920 & 0.467277 & 162.200 & 872.000 \\
\hline PPT & 2880.98 & 0.459482 & 1256.50 & 4534.80 \\
\hline VAT & 497.290 & 0.431449 & 178.100 & 742.000 \\
\hline TTR & 6013.94 & 0.285914 & 3191.94 & 8878.97 \\
\hline
\end{tabular}

Source: Authors' Statistics Summary result.

The table 4.1 above shows that federal government expensed averagely 1041.15 billion naira on developmental projects with a deviation of 59 per cent and ranges from 519.47 to 2681.08 billion naira for the period under consideration. The revenue derived from administration of companies income varies with 46.73 per cent with a mean value of 545 billion naira and ranges from 162 to 872 billion naira. The petroleum profit tax yields average revenue of 2880 billion naira in 10 years with a variation of 46 per cent, minimum and maximum value of 1257 and 4535 billion naira respectively. Value added tax generates an average 497 billion naira in 10 years, varies with 43 per cent and ranges from 178 to 742 billion naira. Revenue derived from taxation in Nigeria from 2009- 2018 averages 6014 billion naira, a variation of 29 per cent and ranges from 3192 to 8879 billion naira

\subsection{Presentation of Ordinary Least Square Result}

In the respect of the specific objectives (one to three) of the study to establish the short-run relationship between variables, the ordinary least square result showing the short-run relationship is presented in the table below: -

Table 2: OLS, using observations 2009-2018 $(\mathrm{T}=10)$, Dependent variable: 1 CAPEX

\begin{tabular}{|l|c|c|c|c|}
\hline & Coefficient & Std. Error & t-ratio & p-value \\
\hline Const & 3.139 & 2.12517 & 1.4771 & 0.19013 \\
\hline 1_CIT & 0.27825 & 2.54632 & 0.1093 & 0.91655 \\
\hline 1 _PPT & -0.0198693 & 0.417965 & -0.0475 & 0.96363 \\
\hline 1_VAT & 0.349158 & 3.02082 & 0.1156 & 0.91175 \\
\hline R-squared & 0.549540 & \multicolumn{2}{|l|}{ Adjusted R-squared } & 0.324311 \\
\hline F $(3,6)$ & 2.439911 & \multicolumn{3}{l|}{ Durbin-Watson } \\
\hline
\end{tabular}

Source: - Authors' Ordinary Least Square result.

From the above table, it could be inferred that the short-run relationship between revenue generated by the government from taxation and capital expenditure can be expressed mathematically below:

^1_CAPEX $=3.14+0.278 * 1 \_$CIT $-0.0199 * 1 \_P P T+0.349 * 1$ VAT

The result above shows that the constant parameter is positively related with total government capital expenditure with a coefficient of 3.14 units, which implies that if all explanatory variables are held constant in the short-run, total government capital expenditure will increase by 3.14 units. Also, companies' income tax showed a positive relationship with capital expenditure with a coefficient of 0.278 which implies that a unit increase in CIT will results to 27.8 per cent increase in revenue expensed on capital expenditure. Petroleum profit tax (PPT) showed a negative effect of 0.0199 on the financing of government development project. The coefficient of the Value Added Tax (VAT) showed a figure of 0.349 units which implies a direct relationship with the dependent variable. It therefore implies that a unit increase the level of value added tax will result into 34.9 per cent increase in the value of total government capital expenditure.

All explanatory variables except petroleum profit tax are in conformity with the prior expectation in the short-run as they showed expected results from the analytical result. The deviation of petroleum profit tax with 
the expected result may be adduced to inefficiency in the administration of tax on petroleum. Meanwhile, the coefficient of multiple determinants $\left(\mathrm{R}^{2}\right)$ showed a coefficient of 0.5495 which implies 54.95 per cent explanation of the behaviour of total government capital expenditure is by the totality of the explanatory variables (PPT, CIT, and VAT) on the short-run. The Adjusted $\mathrm{R}^{2}$ further prove this with the adjusted value of 0.324311 which implies a 32.43 per cent explanation of the behaviour of capital expenditure is by the totality of the explanatory variables with the remaining 67.57 per cent behaviour attributed to other variables outside the model otherwise referred to as the stochastic variables.

\subsection{Tests of Variable Significance (T-Test)}

The T-test is used to test the statistical significance of the explanatory variables in the model. It is done by comparing the T-statistics in the OLS result and the table value (T-tab).

Table 3: T-Statistics

\begin{tabular}{|l|l|l|l|}
\hline Variables & T-Cal & T-tab & Decision \\
\hline Const & 1.4771 & 2.3534 & Insignificant \\
\hline 1_CIT & 0.1093 & 2.3534 & Insignificant \\
\hline 1_PPT & -0.0475 & 2.3534 & Insignificant \\
\hline 1_VAT & 0.1156 & 2.3534 & Insignificant \\
\hline
\end{tabular}

Source: Researchers' T- Statistics result.

The table 2 above shows that all the explanatory variables (CIT-Companies Income Tax, PIT-Petroleum Profit Tax, VAT-Value Added Tax ) does not have significant effect on the spending of government on capital expenditure during the period under consideration which makes null hypotheses $\left(\mathbf{H}_{\mathbf{0}}\right)$ to be accepted for research hypotheses one, two and three.

\subsection{Tests for Overall Significance of Model (F-Test)}

The F-test is used to test the statistical significance of the entire model. This is done to determine the overall significance of behaviour of all explanatory variables adopted in the model. It is done by comparing the Fstatistics in the OLS result and the table value (F-test).

For F-tabulated, the F-distribution value with

$$
\mathrm{K}-1=\mathrm{K}^{\prime}
$$

And N-K degree of freedom @ 95\% confidence level

$$
\begin{aligned}
\text { Hence, }\left(\mathrm{F}_{95}, \mathrm{~V}_{1}, \mathrm{~V}_{2}\right) \text { dof } & \\
\text { Where } \mathrm{V}_{1}=\mathrm{K}-1=\mathrm{K}, & \mathrm{V}_{2}=\mathrm{N}-\mathrm{K} \\
\mathrm{V}_{1}=4-1=3 & \mathrm{~V}_{2}=10-4=6
\end{aligned}
$$

$\left(F_{95} \simeq 3,6\right)$ dof

$\mathrm{F}$-tab $=4.7571$ (as given in the statistical table)

$\mathrm{F}$-cal $=2.4399 \quad($ as given in the OLS result $)$

Since F-cal (2.4399) is lesser than F-tab (4.7571), the model is said to be not to be statistically significant in explaining the behaviour of CAPEX. This is also evidence in the above T-test and the adjusted R-squared, which means taxation, does not spending of government on capital expenditure. This can be presented in a table below:

Table 4: F-Test

\begin{tabular}{|l|l|l|l|l|}
\hline F-calculated & F-tabulated & $\mathbf{H}_{\mathbf{0}}$ & $\mathbf{H}_{\mathbf{1}}$ & Remarks \\
\hline 2.4399 & 4.7571 & Accept & Reject & Insignificant \\
\hline
\end{tabular}

Source: Authors' F-Test result.

The table above shows that F-calculated is lesser than F-tabulated; therefore, we reject the Alternate hypothesis $\left(\mathrm{H}_{1}\right)$ and accept the Null hypothesis $\left(\mathrm{H}_{0}\right)$.

\subsection{Co-Integration Test}

In testing research hypothesis four which is on long run relationship between total tax revenue and government capital expenditure in Nigeria, the co-integration test is used in the determining whether long-run relationship exists between variables. It is in line with the proposition of the Johansen in 1991.

The table below shows the result of the Johansen co-integration test obtained from the co-integration result as duly presented in the appendix

Table 5: Presentation of Johansen Co-Integration Result

\begin{tabular}{|l|l|l|l|l|}
\hline Rank & Eigenvalue & Likelihood Ratio & Lmax test 5\% & $\begin{array}{l}\text { Hypothesised } \\
\text { No of }\left(\mathbf{C E}_{\mathbf{S}}\right)\end{array}$ \\
\hline 0 & 0.45149 & 5.4570 & 5.4050 & $\operatorname{Accept}\left(\mathrm{H}_{1}\right)$ \\
\hline 1 & 0.0057660 & 0.052044 & 0.052044 & $\operatorname{Accept}\left(\mathrm{H}_{1}\right)$ \\
\hline
\end{tabular}

Source: Authors' Co-integration result. 
The table above shows that long-run relationship (co-integration) exists between total tax revenue (TTR) and capital expenditure (CAPEX). This is reflected in the likelihood ratio in the table that shows a value greater than that of the 5 per cent lmax test (critical value). Hence, the hypothesis of no co-integration $\left(\mathrm{H}_{0}\right)$ is rejected and that of presence of co-integration $\left(\mathrm{H}_{1}\right)$ is upheld.

\subsection{Long-Run Model}

From the co-integration result in the Johansen co-integration test above, it could be inferred that there is long-run relationship among the dependent and the explanatory variable. This prompted the need for the establishment of a co-integration model. From the Johansen co-integration result, all log likelihood ratio of the respective cointegrating equations are positively signed. Therefore, the highest log likelihood ratio is chosen. The highest log likelihood ratio is 5.4570 and its corresponding co-integrating equation is stated below;

CAPEX $=-4.6349_{\mathrm{TTR}}-2.59174$

From the above long-run equation, total tax revenue (TTR) and constant parameter are negatively related with government capital expenditure (CAPEX) on the long-run with -4.6349 and -2.59174 respectively.

\subsection{Discussion of Findings}

The study succinctly evaluated the influence of tax revenue on government capital expenditure and economic growth in Nigeria using both qualitative and quantitative approach. The short-run analysis showed that companies' income tax (CIT) and value added tax (VAT) are positively related to capital expenditure (CAPEX), on the contrary, petroleum profit tax showed an inverse relationship with capital expenditure (CAPEX). In determining the goodness of fit of the model, the coefficient of multiple determinants $\left(\mathrm{R}^{2}\right)$ showed a coefficient of 0.5495 which implies 54.95 per cent explanation of the behaviour of total government capital expenditure is by the totality of the explanatory variables (PPT, CIT, and VAT) on the short-run. The Adjusted $\mathrm{R}^{2}$ further prove this with the adjusted value of 0.324311 which implies a 32.43 per cent explanation of the behaviour of capital expenditure is by the totality of the explanatory variables with the remaining 67.57 per cent behaviour attributed to other variables outside the model otherwise referred to as the stochastic variables. Testing the significance of the explanatory variables of each research hypotheses on the explained variable using T-test, It was showed that all the explanatory variables (CIT- Companies Income Tax, PIT- Petroleum Profit Tax, VATValue Added Tax) does not have significant effect on the spending of government on capital expenditure during the period under consideration which makes null hypotheses $\left(\mathbf{H}_{\mathbf{0}}\right)$ to be accepted for research hypotheses one, two and three.

Also, the F-test used in the determination of the overall significance of the whole model was carried out and it revealed that the model is not statistically significant at 95 per cent level of confidence (5 per cent significance level). This implies that taxation does not explain the spending of government on capital expenditure. Meanwhile, the Johansen co-integration test revealed that negative long-run relationship (co-integration) exist between total tax revenue (TTR) and capital expenditure (CAPEX) which contradict the findings of Saeed and Somaye (2012) who disclosed unidirectional long run positive relationship between tax revenue and government expenditure.

\subsection{Conclusion and Recommendation}

This research work critically evaluated the relationship between tax revenue on government capital expenditure and economic growth in Nigeria with the use of both qualitative and quantitative approach in other to determine the significant impact of various taxes administered in Nigeria on the overall government capital expenditure.

The research work revealed majorly that the revenue derived from taxation in Nigeria from 2009 to 2018 has been impressive over the period but not efficient. This is in conformity with the findings of Onaolapo, Aworemi \& Ajala (2013); Abiola \& Asiweh (2012); Oziengbe (2013). Furthermore, the study showed that companies' income tax (CIT) and value added tax (VAT) are positively related to total government capital expenditure (CAPEX) while petroleum profit tax (PPT) showed an inverse relationship with total government capital expenditure. Based on T-test which test significance of the explanatory variables of each research hypotheses on the explained variable, It is revealed that all the explanatory variables (CIT-Companies Income Tax, PIT-Petroleum Profit Tax, VAT-Value Added Tax) does not have significant effect on the spending of government on capital expenditure during the period under consideration which makes null hypotheses (Ho) to be accepted for research hypotheses one, two and three and supported the findings of Oziengbe (2013) that showed insignificant relationship exist between capital expenditure and overall government revenue. In addition, based the F-test and coefficient of determination it is disclosed that the whole model was not significant in explaining the relationship between the dependent variable which is captured by the Total government capital expenditure (CAPEX) and three explanatory variables which are companies' income tax (CIT), petroleum profit tax (PPT), value added tax (VAT), while negative long-run relationship (co-integration) exist between total tax revenue (TTR) and capital expenditure (CAPEX) which contradict the findings of Saeed and Somaye (2012) who disclosed unidirectional long run positive relationship between tax revenue and government expenditure. 
Therefore, taxation is a monetary charge levied on citizens by government in other to make funds available to perform its statutory responsibilities to the people. In Nigeria though the contribution of taxation to total government revenue have been impressive over the period but it is insignificant if compared to the revenue derived from petroleum which is regarded as oil revenue and other most advanced countries of the world in which their economy is tax driven.

Based on the findings of the study, it is concluded that tax revenue does not impact the spending on capital expenditure in the sense that companies income tax which is the tax charged on companies' profit does not have a corresponding significant impact on the spending of government on developmental and infrastructural projects which will encourages the payment of tax by reducing evasion and avoidance of tax and also directly influence industrialization which will increase revenue derivation from companies income tax.

The administration of petroleum profit tax for the period under consideration does not granger-cause government spending on capital expenditure of the government, while the tax on value added to goods and services exhibited insignificant effect on government expenditure.

The contributions of tax revenue to government revenue and indirectly to total government spending cannot be overemphasized in Nigeria, but these contributions can still be enhanced if the following are adopted by the government.

- $\quad$ The use of presumptive tax, where small scale trader are asked to pay a particular amount because they cannot afford auditors and accountants that will help them in the preparation of financial statement that is suitable for tax purpose so that there will be increase in government revenue and minimize deficit spending.

- $\quad$ The use of aggressive tax drive, where by defaulters are taken to court and asked to pay heavy penalty. The utilization of tax revenue on public goods will encourage the payment of tax by tax payers. This should be implemented where by any tax revenue expended on public goods should be indicated and that the chairman of federal Inland Revenue service should be a member of federal executive council (FEC) in other to influence this move.

- The policy implication derivable from this study is that the increase in government expenditure without corresponding revenue will widen the budget deficit. Thus, government will be left with an option to borrow which could increase indebtedness to lending countries and institutions.

- Government should reduce the size of large recurrent expenditure and move towards capital and other investment expenditures. The cost of running the government should be reduced, ghost workers as well as redundant ones should be terminated and funds recovered from such put to investment use. Deliberate efforts should be made to check inflation of contracts sums, these will help reduce budget deficit.

- Government should diversify the economy. Other sources of revenue should be explored especially the non-oil minerals sector so as to correct the disparity between revenue and expenditure and reduce the attendant budget deficit.

- Taxes have a role to play in the economy especially in deemphasizing the mono-economic (petroleum sector) nature of Nigeria. Expenditure reforms analysis should be considered vis-à-vis taxes and all other revenues sources (oil and non-oil) reforms; this will help set targets for revenue mobilization and utilization as well as expenditure spreading over the entire economy.

\section{References}

Abiola, J. \& Asiweh, M. (2012). Impact of tax administration on Nigeria, International Journal of Business and Social Science, Volume 3 No. 8 (Special Issues, April)

Adams, C. (2001). For Good and Evil: The impact of Taxes on the Course of Civilization. U.S.A.; Madison Publishers.

Adegbie, F. F \& Fakile, A. S. (2011). “Company Income Tax and Nigeria Economic Development”, European Journal of Social Sciences, 22(2)

Aguolu. O. (2004) Taxation and Tax Management in Nigeria, 3rd Edition, Enugu: Meridan Associates.

Al-Qudair, K. H. (2005). 'The Relationship between Government Expenditure and Revenues in the Kingdom of Saudi Arabia: Testing for Cointegration and Causality', Journal of King Abdul Aziz University: Islamic Economics, 19 (1), 31-43.

Basu, K. (2000). On the goals of development. In G. M. Meier \& J. E. Stiglitz (Eds.), Frontiers of development economics: The future in perspective (pp. 61-86). Washington, D.C.: World Bank and Oxford University Press.

Bhartia, H. L. (2009). Public Finance. 14th Edn., Vikas Publishing House PVT Ltd, New Delhi.

Dewett, K. K. (2005). Modern Economic Theory. Shyam Lal Charitable Trust, New Delhi, India.

Hye, Q.M.A. \& Jalil, M. A. (2010). Revenue and expenditure nexus: A case study of Rornania. Rornanian Journal of Fiscal Policy, 1(1): 22-28. 
Jhingan. M. L. (2006). The Economics of Development and Planning, 38th Edition. Virnda Publication (P) Ltd., Delhi.

Jhingan, M. L. (2004). Money, Banking, International Trade and Public Finance. Vrinda Publications, New Delhi.

Johansen, S. (1991). Estimation and hypothesis testing of cointegrating vector in Gaussian vector autoregression models. Econometrica 59: 1551-1580.

Joint Tax Board Handbook (2011)

Keho, Y. (2010). Budget Balance through Revenue or Spending Adjustments? An Econometric Analysis of the Ivorian Budgetary Process, 1960- 2005. Journal of Economics and International Finance, 2 (1), pp. 001-011.

Keho, Y. (2010). "Estimating The Growth-Maximizing Tax Rate for Cote d'Ivoire, 1960-2007", J. Econ. Int. Finan.; 2(9):164-174.

Maku, O. E. (2009). Does Government Spending Spur Economic Growth in Nigeria? MPRA Paper No. 17941.

Musa, W. E. (2009). Tax Planning and Economic Development, International Research Journal on Economics, ISSN 1450-2887, 5 (4): 134-141.

Musgrave, R. A. \& Musgrave, P. B. (2004). Public Finance in Theory and Practice. Tata McGraw Hill, New Delhi, India.

Naiyeju, J. K. (1996). Improving the Nigeria tax system from Canadian experience. Wordsmith Printing and Packaging Ltd. pp: 101-104.

Nazifi, A. D. (2014). Federal Capital Expenditure and its impact on Economic Growth in Nigeria; 1980-2010. Developing Country Studies, ISSN 2224-607X (Paper) ISSN 2225-0565 (Online) Vol.4, No.4.

Nwaeze, C. (2010). Public Financial Management: Theory and Practice. Reconciliation Publishers Limited, Aba.

Nwankwo C. S (1992). Nigeria Income Tax Law and Practice. Ibadan: Heinemann Educational Books (Nig.) Plc.

Ochejele, J. J. (2007). Economic Analysis. Ichejum Press, Jos.

Ola, C.S. (2001). Income Tax Law and Practice in Nigeria, 5th edition, Ibadan, Dalag Prints and Park.

Ola, S.C. (1999). Income Tax Law and Practice in Nigeria. Ibadan: Heinemann Educational Books (Nig) plc.

Olopade, B. C \& Olopade, D. O. (2010). The Impact of Government Expenditure on Economic Growth And Development In Developing Countries: Nigeria As A Case Study

Oluba, M. N. (2008). “Justifying Resistance to tax payment in Nigeria”, Economic Reflections Volume B, No 3, April.

Osho, A. E. Omotayo, A. D. \& Ayorinde, F. M. (2018). Impact of Company Income Tax on Gross Domestic Products in Nigeria. Research Journal of Finance and Accounting. United Kingdom. ISSN 2222-1697 (Paper) ISSN 2222-2847 (Online) Vol.9, No.24. pp. 105-115.

Osmond N. O., Nnamocha, P. N. \& Emmanuel, I. A. (2015). Impact ofExpanding Economic Activities onGovernment Expenditure inNigeria. IOSR Journal of Economics and Finance (IOSR-JEF) e-ISSN: 23215933, p-ISSN: 2321-5925.Volume 6, Issue 5. Ver. I (Sep. - Oct. 2015), PP 01-09

Onaolapo, A. A., Aworemi, R .J. \& Ajala, O. A. (2013). Assessment ofValue Added Tax and Its Effects on Revenue Generation in Nigeria, International Journal of Business and Social Science. Vol. 4, No.1

Oziengbe, S. A. (2013). The relative impacts of federal capital and recurrent expenditures on Nigeria's Economy. American Journal of Economics, 3(5): 210-221.

Saeed, K. P. \& S. Somaye, S. (2012). Relationship between government spending and revenue: Evidence from oil exporting countries. International Journal of Economics and Management Engineering (IJEME), 2(2): 33-35.

Samuel, S.E. and Simon, S. (2011). The Effect of Income Tax on Capital Investment Decisions of Banks in Nigeria. Kogi Journal of Management, 4(1), 116-128.

Sani, A. (2005). "Contentious issues in tax administration and policy in Nigeria: A governor's perspective". First National Retreat on Taxation. Lagos: Joint Tax Board.

Tax Justice Network [TJN) (2012). Aid, tax and finance for development.

Todaro, M., \& Smith, S. (2003). Economic development (8th ed.). Boston: Addison Wesley.

Unegbu, O. A. \& Irefin, D. (2011). "Impact of VAT on Economic Development of Emerging Nations", Journal of Economic \& International Finance, Vol.3, Issue 8, pp. 492-503.

United Nations (2000). "Resource Mobilization for Economic Development: The Role of Tax Administrator", United Nations study in conjunction with Association de Planification Fiscale Financiere.

Yunusa, A.A. (2003). Understanding the Principles and Practice of Taxation in Nigeria. Lokoja: Jimsy Color print

Zinaz, A. \& Sarnina, K. (2010). Government expenditure and tax revenue, causality and co-integration. The Experience of Pakistan 1972-2007. 